Kinestetik : Jurnal Ilmiah Pendidikan Jasmani 4 (2) (2020)

Kinestetik : Jurnal Ilmiah Pendidikan Jasmani

https://ejournal.unib.ac.id/index.php/kinestetik/index

\title{
THE INFLUENCE OF TEACHING STYLE AND FLEXIBILITY ON KAYANG LEARNING OUTCOMES
}

\section{Fitriana Puspa Hidasari' ${ }^{1}$, Muhammad Fachrurrozi Bafadal ${ }^{2}$}

${ }^{12}$ Physical Education, Faculty of Teacher Training and Education, Universitas Tanjungpura, Indonesia

\section{Article Info}

\section{Article History:}

Received September 2020

Revised September 2020

Accepted September 2020

Available online September 2020

Keywords: Kayang Learning Outcomes, Flexibility, Teaching Style

\begin{abstract}
The purpose of this study was to see how much difference the impact of the two teaching styles, flexibility on learning kayang. The sample was students of SMP 6 Pontianak City, totaling 48 students, which were divided into 4 groups, with details consisting of 12 students per group. Quantitative method which has the form of Experiment with FACTORIAL design by level $2 \times 2$ is a research method. Two-way analysis of variance is a way of analyzing in this study, followed by a normality test and a homegeneity test. After that, the Tukey test was continued with a significance level of $a=$ 0.05 . This research has succeeded in answering several hypotheses that have been proposed. The first is the Inclusive Teaching Style (GMI) has a significant effect compared to the Exercise Teaching Style (GML) on kayang learning outcomes. The second is that GMI and GML have a strong interaction with the rich learning outcomes. The third is that GMI is more appropriate to be applied than GML for students who have high flexibility in the learning outcomes of kayang. The fourth is that GML is more appropriately applied compared to GMI in students who have low flexibility in the learning outcomes of kayang.
\end{abstract}




\section{INTRODUCTION}

Floor gymnastics is gymnastics whose movements are carried out on the mat, the elements include jumping, rolling, jumping, and spinning in the air and supporting with hands and feet. (Fis Andriyani, 2012). Floor exercise is a part of physical education materials. This is especially true for Junior High Schools (SMP). There are several floor exercise materials listed in the junior high school curriculum consisting of front roll, back roll, tiger jump, candle stance, standing with both hands, back flip, forward somersault, hand bending, bending bending, cartwheeling and loving attitude (Samsudin, 2008 ). Some of the materials were felt to be difficult for students to do, including one of them is kayang.

Kayang is a skill in floor gymnastics that requires flexibility of the waist, shoulders and arms. The kayang movement can be started from standing or from sleeping on your back on the mat. Before doing kayang movements, it must be started with a warm up and stretching sufficiently so that the body temperature increases so that the muscles and joints become ready to contract while doing kayang and avoid mistakes and injuries. To avoid mistakes in doing kayang required a tiered and structured planning from easy to difficult levels.

The phenomenon that occurs is inversely proportional to the conditions in the field. Mistakes in doing kayang often occur in physical education lessons at SMP Negeri 6 Pontianak. Based on the writer's information and observations with the physical education teacher (penjas) at SMP Negeri 6 Pontianak, it shows that in the implementation of kayang there are still deficiencies in doing so, more specifically, many male students are less able to do it than female students. This is because students feel afraid that if they do kayang their head will have a collision on the mat, kayang movements cause the student's body to become sick and students do not really do kayang learning. The impact of that.

There are several other problems found by Physical Education teachers in the Kayang learning material. The author found that the students 'arm, shoulder and hand muscles were less strong in supporting the body, the students lacked flexibility in their waist, when the students' heads were bouncing upward, and the distance between the arms and legs was too far and added to the fear before doing the kayang movement. $74 \%$ of students felt very heavy fear and anxiety when doing kayang(I Wayan Eka Putra, 2013) It is necessary to convey the correct goals in the implementation of kayang so that students do not feel afraid.

A suitable learning approach and method is needed to overcome the problems in kayang learning, so teachers are required to be more creative in choosing various teaching styles. Referring to the results of research on kayang, it shows that students are more interested in doing kayang movements with many variations in teaching styles and media provided by the teacher than just given conventionally so as to improve learning outcomes(Daryusman et al., 2014; Suryani et al., 2018; Wandi Suhendra, 2019).

Lots of research results discuss the effect of teaching styles on floor exercise, but there is no research that examines the effect of teaching styles on learning outcomes, especially GMI and GML. In line with research results(Muhammad Mury Syafei, 2016)states that to solve the problem of floor gymnastics learning by providing several learning styles. The right strategies to improve the learning outcomes of kayang movements are GMI (GMI) and GML (GML). 
GMI (GMI) is a teaching style in which the learning process describes systematic difficulty levels and aims to make it easier for students to complete their learning, choose their level of ability and are given the freedom to determine the number of repetitions. Meanwhile, GML (GML) is a learning process that performs a large number of repetitive movements or exercises resulting in an increase in learning outcomes.

Besides using the right teaching style and good body components are also needed, to facilitate success in learning kayang. A physiological component is needed, in this case a component related to physical ability, namely flexibility. Flexibility in kayang movements are needed as at the start, and when the body bends technique and when the hands are back so that the hands touch the floor and form an arc and the final stage of the bouncy standing movement. Likewise, success in learning floor gymnastics, apart from being determined by the teacher's ability to apply teaching styles, is also supported by good flexibility that must be possessed by students. (Muhammad Mury Syafei, 2016).

\section{METHOD}

Quantitative method with the form of experimental research with factorial design By Level $2 \times 2$ is the method in this study. There are several variables in this study, the independent variable is the teaching style which is divided into two types, namely (1) GML, and (2) GMI, the attribute variable is flexibility which is divided into two, namely (1) high flexibility, and (2) low flexibility., and the dependent variable is a rich learning result. The following will be described in table 1 is:
Table 1. Factorial Design By Level 2 x 2

\begin{tabular}{|c|c|c|}
\hline $\begin{array}{l}\text { Teaching Style } \\
\text { (A) }\end{array}$ & $\begin{array}{l}\text { Inclusion } \\
\quad \text { (A1) }\end{array}$ & $\begin{array}{c}\text { practice } \\
\text { (A2) }\end{array}$ \\
\hline $\begin{array}{l}\text { High Flexibility } \\
\text { (B1) }\end{array}$ & A1B 1 & $\mathrm{~A} 2 \mathrm{~B} 1$ \\
\hline $\begin{array}{l}\text { Low Flexibility } \\
\text { (B2) }\end{array}$ & $\mathrm{A} 1 \mathrm{~B} 2$ & $\mathrm{~A} 2 \mathrm{~B} 2$ \\
\hline Total & A1 & $\mathrm{A} 2$ \\
\hline
\end{tabular}

Population and sample

Class VII students at SMP N 6

Pontianak were the population of this study, totaling 183 students. The sampling technique uses a sample area (cluster sampling). This technique is used in two stages, the first is to determine the two desired classes from 6 (six) groups by randomly. The second stage, after obtaining the two desired classes, the two classes are class VII C totaling 35 and VII $\mathrm{F}$ totaling 72 , then the two classes are tested to determine the high and low categories of student flexibility.

The test results are arranged according to the scores obtained and then ranked. And samples were taken with a value of $33 \%$ top ranking and lower ranking. Thus a total of 72 students in the upper limit category was $33 \%$ from $72=$ 23.76 or rounded to 24 samples, and $33 \%$ of the lower limit category students were from $72=23.76$ or rounded to 24 samples of the lower limit and each group the upper limit. consisting of 24 students from the lowest score and 24 students from the highest score.

The sample in the middle should be removed. So, the total sample of this study amounted to 48 students, which consisted of 4 groups. The four treatment groups referred to were: two from the high flexibility group taught GMI and training and two from the low flexibility group taught GML and inclusion. Then in the 
selection in each cell the design uses the split half technique selection, which is dividing the two groups in a way selection from the ranking results of the high flexibility test using odd numbers where the GMI group is placed and even numbers place the GML group and vice versa the selection method applies the same for low flexibility.

\section{Research Instruments}

This research instrument has two types of tests, namely: (1) widiastuti's flexibility test. Implementation of flexibility tests using standard tools, namely Widiastuti's upper and neck flexibility static tests, so validity and reliability testing is no longer carried out (2). Kayang learning outcomes test.

\section{Kayang Learning Outcomes \\ Instrument grille}

The validity of the contents of the tests conducted is to use expert validity. The assessment instrument for kayang learning outcomes was validated by 3 experts who were experts in the field of floor exercise, especially kayang, consisting of two floor gymnastics lecturers, a physical education teacher at junior high school.

The results of the calculation of the reliability of the kayang learning outcome instrument were 0.771 , with $\mathrm{r}$ table $=$ 0.349 . So, rhitung $=0.771>\mathrm{r}$ table $=$ 0.3494 so that the research instrument was reliability.

\section{Research Implementation Stages}

The time for the research was carried out through the following stages: (1) Instrument Testing in mid-February 2019, (2) Treatment or treatment was carried out from March 2019 to May 2019

(3) followed by a final test in May 2019.

(4) Data analysis was carried out May June 2019.
The sample determination test was carried out to collect data about the initial flexibility possessed by students to be given teaching methods. The results of this flexibility test serve as a reference for determining each group that has high and low flexibility.

Pretest

The initial test was carried out using the kayang test. Students are given the opportunity to do the test. After getting the pretest, it is continued by applying treatment or treatment.

\section{Treatment}

The treatment was given as many as 10 meetings which were conducted once a week. Then the treatment is given in the form of kayang movements using GMI with the material consisting of low levels using a gym ball, moderate levels using the help of friends and high levels, students doing kayang themselves from a standing position. Then this method was given by 2 groups consisting of low and high flexibility groups each having 12 people in each group.

The application of GML carried out in this study is to do kayang continuously. And the group that was given this training method was a group that had high and low flexibility, amounting to 12 students per group.

\section{Post test}

After carrying out a long treatment, it was continued by doing a posttest, namely the kayang test for all groups.

Data analysis technique

The data analysis technique used the 2-way analysis of variance (ANOVA) technique with a significant level $=0.05$. Before carrying out the Anava test, a prerequisite test is needed, namely the normality test using the Lillefors test and after that, it is followed by a homogeneity test using the Bartlet test. Then if there is 
an interaction, it will be tested using the Tukey Test. $\propto$.

\section{RESULTS AND DISCUSSION}

This chapter presents several descriptions of research results consisting of data descriptions, prerequisite test presentations, proving hypotheses, and discussing research results juxtaposed with the theories and research results of other researchers.

\section{Data Description}

The research implementation took place within 60 days which consisted of a flexibility test which aimed to determine the high and low flexibility of the sample, which were then grouped into groups of students who had high flexibility taught with GMI and GML while groups of students who had low flexibility were taught with GML and GMI. After dividing the groups, a series of preprogrammed treatments was given to students according to the group. Then the kayang test is carried out to obtain data on kayang learning outcomes in the form of analyzed scores. Furthermore, the students' learning outcomes data were analyzed by collecting data for each group which is described in table 4 below:

Table 4. Summary of Calculation Results Kayang Learning Outcomes Data

\begin{tabular}{cll}
\hline Flexibility (B) & \multicolumn{2}{c}{ Teaching Style (A) } \\
& \multicolumn{1}{c}{ Inclusion (A1) } & Practice (A2) \\
& $\sum X=403$ & $\sum X=299$ \\
HIGH & $\sum X^{2}=13609$ & $\sum X^{2}=7529$ \\
(B1) & $\bar{x}=33.58$ & $\bar{x}=24.92$ \\
& $\mathrm{~S}=2.60$ & $\mathrm{~S}=2.67$ \\
& $\mathrm{~N}=12$ & $\mathrm{~N}=12$ \\
& & \\
LOW & $\sum X=311$ & $\sum X=369$ \\
(B2) & $\sum X^{2}=8137$ & $\sum X^{2}=11397$ \\
& $\bar{x}=25.92$ & $\bar{x}=30.75$ \\
& $\mathrm{~S}=2.64$ & $\mathrm{~S}=2.13$ \\
& $\mathrm{n}=12$ & $\mathrm{~N}=12$ \\
TOTAL & $\sum X=714$ & $\sum X=668$ \\
& $\sum X^{2}=21746$ & $\sum X^{2}=18926$ \\
& $\bar{x}=29.75$ & $\bar{x}=27.83$ \\
& $\mathrm{~S}=4.68$ & $\mathrm{~S}=3.80$ \\
& $\mathrm{~N}=24$ & $\mathrm{~N}=24$ \\
\hline
\end{tabular}

Prerequisite testing is done by testing the normality and homegeneity test.

Normality test

The use of the Liliefors test to test the normality of kayang learning outcomes in each group can be explained below, namely:

Table 5. Summary of Normality Test Results

\begin{tabular}{ccccc}
\hline Group & N & L0 & Lt & Conclusion \\
\hline A1 & 24 & 0.096 & 0.181 & Normal \\
A2 & 24 & 0.135 & 0.181 & Normal \\
A1B1 & 12 & 0.127 & 0.256 & Normal \\
A1B2 & 12 & 0.115 & 0.256 & Normal \\
A2B1 & 12 & 0.217 & 0.256 & Normal \\
A2B2 & & 0.203 & 0.256 & Normal \\
\hline
\end{tabular}

accepted. Then the entire Lohitung group is smaller than Ltabel to complete the prerequisite test, one more requirement is needed, namely the homogeneity test.

\section{Homogeneity Test}

The normality test of the kayang learning outcomes score was carried out using the Bartlett test at the significance level $\alpha=0.05$. The first variance homogeneity test was carried out on two groups of teaching styles, namely GMI (A1) and GML (A2). The test results are as follows.

Table 6. Homogeneity Test Results

\begin{tabular}{cccccc}
\multicolumn{5}{c}{ on Results } \\
\hline Group & $\begin{array}{c}\text { Varian } \\
\text { ce }\end{array}$ & $\begin{array}{c}\text { Combi } \\
\text { ned } \\
\text { Varian } \\
\text { ce }\end{array}$ & $\begin{array}{c}\text { X2 } \\
\text { cou } \\
\text { nt }\end{array}$ & $\begin{array}{c}\text { X2 } \\
\text { table }\end{array}$ & $\begin{array}{c}\text { Conclusi } \\
\text { on }\end{array}$ \\
\cline { 1 - 2 } A1 & 21.93 & 30.98 & 1.8 & 2.78 Homogen \\
A2 & 40.03 & & 2 & eous \\
\hline
\end{tabular}

The results of the calculations described in table 4.9, obtained X2count $=$ $1.82<2.78=\mathrm{X} 2$ table at the significance level $\alpha=0.01$, then $\mathrm{H} 0$ is accepted, which 
means that the two data groups come from a homogeneous population.

The second homogeneity test was carried out on 4 groups, namely the GMI group with high flexibility (A1B1), the GMI group with low flexibility (A1B2), the GML group with high flexibility (A2B1), the GML group with low flexibility (A2B2). The test results are as follows.

Table 7. Results of the Calculation of the Homogeneity Test of Kayang Learning Results in 4 Groups

\begin{tabular}{cccccc}
\hline Group & $\begin{array}{c}\text { Vari } \\
\text { ance }\end{array}$ & $\begin{array}{c}\text { Varian } \\
\text { ce } \\
\text { Combi } \\
\text { ned }\end{array}$ & $\begin{array}{c}\mathrm{X} 2 \\
\text { cou } \\
\text { nt }\end{array}$ & $\begin{array}{c}\text { X2 } \\
\text { tabl } \\
\mathrm{e}\end{array}$ & $\begin{array}{c}\text { Conclusio } \\
\mathrm{n}\end{array}$ \\
& & & & & \\
\hline $\begin{array}{c}\text { (A1B1 } \\
\text { ) }\end{array}$ & 6.81 & 6.38 & 0.701 & 7.8 & $\begin{array}{c}\text { Homogen } \\
\text { eous }\end{array}$ \\
$\begin{array}{c}\text { (A1B2 } \\
\text { ) }\end{array}$ & 6.99 & & & 1 & \\
$\begin{array}{c}\text { (A2B1 } \\
\text { ) }\end{array}$ & 7.17 & & & & \\
$\begin{array}{c}\text { (A2B2 } \\
\text { ) }\end{array}$ & 4.57 & & & & \\
\hline
\end{tabular}

Looking at the table 4.10 above, it is found that X2count $=0.701<7.81=\mathrm{X} 2$ table at the significance level $\alpha=0.05$, then $\mathrm{HO}$ is accepted, which means that the four data groups come from a homogeneous population. Because the two requirements have been met, it can be continued with the analysis of variance test (ANOVA).

Hypothesis test

Two-way analysis of variance is a computation technique (parametric statistics) that aims to investigate two influences, namely the main effect is the effect of differences in teaching styles (inclusion and training) on learning outcomes. While the effect of interaction is the effect of interaction between teaching styles and flexibility on learning outcomes of kayang.
Table 8. Anava Calculation Summary of Kayang Learning Results

\begin{tabular}{|c|c|c|c|c|c|}
\hline $\begin{array}{l}\text { Source of } \\
\text { variance }\end{array}$ & $\begin{array}{l}\mathrm{D} \\
\mathrm{b}\end{array}$ & $\mathrm{Jk}$ & Rjk & $\begin{array}{c}\text { Fcou } \\
\text { nt }\end{array}$ & $\begin{array}{c}\text { Ftabl } \\
\mathrm{e}\end{array}$ \\
\hline $\begin{array}{l}\text { Between } \\
\text { Lines } \\
\text { (Teaching } \\
\text { Style) }\end{array}$ & 1 & 44.08 & 44.08 & 6,903 & 4.06 \\
\hline $\begin{array}{l}\text { Between } \\
\text { columns } \\
\text { (Flexibilit } \\
\text { y) }\end{array}$ & 1 & 10.08 & 10.08 & 1,579 & \\
\hline $\begin{array}{l}\text { Interactio } \\
\mathrm{n}\end{array}$ & 1 & $\begin{array}{c}546.7 \\
5\end{array}$ & $\begin{array}{c}546.7 \\
5\end{array}$ & $\begin{array}{c}85,61 \\
2 \\
\end{array}$ & \\
\hline In & 44 & $\begin{array}{c}281.0 \\
0\end{array}$ & 6.39 & & \\
\hline $\begin{array}{l}\text { total } \\
\text { correction }\end{array}$ & 47 & $\begin{array}{c}881.9 \\
2\end{array}$ & & & \\
\hline
\end{tabular}

Based on table 8 , because there is an interaction between learning outcomes and flexibility, a further test is carried out, namely the Tukey test because the number of samples is the same. The follow-up test is intended to find out about (1) the comparison of kayang learning which has high flexibility given by GMI and training. (2) comparison of kayang learning which has low flexibility given GML and inclusion. The following table 9 below is the result of the Tukey Test calculation:

Table 9. Tukey Test calculation results

\begin{tabular}{ccccc}
\hline No. & $\begin{array}{c}\text { Groups } \\
\text { being } \\
\text { compared }\end{array}$ & Qcount & Qtabel & Information \\
\cline { 1 - 2 } 1. & $\begin{array}{c}\text { A1B1 } \\
\text { with }\end{array}$ & 11.88 & 3.77 & Significant \\
& A2B1 & & & \\
\cline { 1 - 2 } & A1B2 & 6.63 & & Significant \\
& with & & & \\
& A2B2 & & & \\
\hline
\end{tabular}

Comparison of Learning Outcomes Between GMI and GML

Based on the analysis of variance (ANOVA) at the significant level $\alpha=0.05$, it was found that Fcount $=6,903$ and 
Ftable $=4.06$. Thus Fo $>\mathrm{Ft}$, so that $\mathrm{Ho}$ is rejected, so it can be concluded that, GMI and GML have a significant difference to the results of kayang learning. These results prove that GMI is better or more suitable to be applied in kayang learning when compared to GML.

The interaction between teaching style and flexibility on learning outcomes.

Based on the calculated interaction price $\mathrm{Fh}(\mathrm{FAB})=85.6$ and $\mathrm{F}$ table $=7.24$ with a significant error level $\alpha=0.01$. It can be seen that $\mathrm{F}$ count $>\mathrm{F}$ table, so $\mathrm{H} 0$ is rejected. and $\mathrm{H} 1$ is accepted. It can be concluded that there is an interaction between teaching style and flexibility on kayang learning outcomes.

GMI and exercise provide a significant difference to the learning outcomes of kayang for groups with high flexibility. of students who have high flexibility, who are taught $\mathrm{P} 1$ and $\mathrm{P} 2$ have the results $\mathrm{Qh}=11.88$ and $\mathrm{Qt}=3.77$. Thus $\mathrm{Qh}$ is greater than Qt, so Ho is rejected. It can be concluded that the group of students who have high flexibility shows that the GMI $(\bar{X}=33.58)$ better when compared to GML ( $\bar{X}=24.92)$.

Comparison of GMI and GML on Kayang Learning Outcomes for Low Flexibility Groups.

There is a significant difference between the GML and the GMI on the learning outcomes of kayang for groups with low flexibility. The results of this calculation are proven and the results of the Tukey Test calculations in this group can be explained in table 11 below:

Table 10. Group Comparison GML And GMI For Low Flexibility.

\begin{tabular}{ccccc}
\hline No. & $\begin{array}{c}\text { Groups } \\
\text { Compared }\end{array}$ & $\begin{array}{c}\text { Q } \\
\text { cou } \\
\text { nt }\end{array}$ & $\begin{array}{c}\text { Q } \\
\text { table }\end{array}$ & Information \\
\hline 2 & P4 with P3 & 6.63 & 3.77 & Significant \\
\hline
\end{tabular}

In the group of students who have low flexibility who are taught with GMI (P4) and GML (P3), the results are, $\mathrm{Qh}=$ $6.63<\mathrm{Qt}=3.77$ That is, Ho is accepted and $\mathrm{H} 1$ is rejected. It can be concluded that the group of students who have low flexibility are taught the GML $(\bar{X}=30.75)$ is better than GMI ( $\bar{x}=25.92)$.

\section{DISCUSSION}

The application of GMI (A1) is better than GML (A2) on the comprehensive learning outcomes.

Kayang is one of the basic movements in floor exercise material. Every student must be able to master the kayang movements. For that, in order to do so we need athe right teaching style to master the kayang. In this study, applying two styles, namely the style of teaching exercises and inclusion. And these two styles have differences.

Anava calculation results about the comparison of the effects between the two teaching styles. It can be concluded that GMI has a better impact than GML on learning outcomes. Therefore, GMI is more suitable to be applied in improving the floor exercise material more specifically. This is in line with the research results(Aji, 2017; Hidayat, 2008)that GMI can improve learning outcomes for floor exercise and physical education learning outcomes. In its implementation, students enjoy the learning process which is considered more creative and innovative. Students are more interested in participating in GMI than in commando and GML teaching styles in doing physical activities(Sanchez et al., 2012). Students think of the inclusive teaching style as a new way of teaching so that students are more enthusiastic and 
motivated. The learning outcomes of floor gymnastics will increase if students have high motivation too(Priyambada et al., 2016).

There is an interaction between teaching style and flexibility on Kayang learning outcomes. From these data it can be concluded that there is an interaction between the styles of teaching with flexibility on learning outcomes kayang. (Heri Rahyubi, 2012)stated that learning is the process of interaction between students and educators and learning resources in a learning environment. The interaction of students with the learning environment is designed to achieve learning objectives, including increased motivation and student learning outcomes. What is meant in the designed learning environment is the teaching style, namely GMI and training.

Teaching style designed with 2 styles that result in significant changes, which lead to an increase in learning outcomes of floor gymnastics, especially kayang material. While the statement poured by(Terry, 2016) contrary to the above interaction which states that the teaching style has no interaction with flexibility on the learning outcomes of floor exercise. Thus it can be concluded that there is an interaction between teaching style and flexibility to the learning outcomes of kayang. For students who have high flexibility, the learning outcomes through the implementation of GMI (A1) are better than GML (A2).

Thus the second hypothesis $\left(\mathrm{H}_{0}\right)$ which states that there is no difference in learning outcomes for students who have high flexibility between students who are taught using GMI and GML is rejected. The statistical test shows that there is a very significant difference in kayang learning outcomes in groups of students who have high flexibility between GMI and GML.
Both of these methods serve a purpose the same, namely improving learning outcomes, but each has differences in terms of implementation. In its implementation, GML emphasizes students to perform kayang movements repeatedly in order to master these movements. Meanwhile, in its implementation, GMI emphasizes the presentation of learning material as a whole in detail, describing the level of difficulty.(Hidasari et al., 2018) In other words, students are given the freedom to choose and determine the level of difficulty students have to start learning.

For students who have high flexibility in their implementation GML is an activity that is usually carried out and does not have high challenges, because according to students the teaching style is very easy and simple so that it does not cause high motivation and the element of competition is very small in increasing the ability to move, thus the results to be achieved are also not as expected. expected. In other words, learning with the application of training teaching styles for students who have high flexibility does not cause an element of motivation and competition. Meanwhile, students who have high flexibility are taught GMI is more motivated in the implementation of learning, this is because students are given the freedom to choose the level of difficulty so that they can independently complete learning assignments correctly.

Thus, based on the discussion of research results, it is for For students who have high flexibility, the application of GMI is better when compared to GML in learning floor exercise, especially the material of kayang. For students with low flexibility, good learning outcomes through the implementation of GML (A2) are better than GMI (A1) Second This teaching style has the same goal, namely to improve the learning outcomes of 
kayang, but each has differences in terms of implementation.

In practice, the group of students who have low flexibility taught by GML emphasizes students on repetition of kayang movements so that students who have low flexibility get new learning experiences in doing kayang movements such as more relaxed doing kayang, the muscles of the body are more ready to do kayang and great fun. The author designed, before doing kayang students were brought to play related to kayang material, this functioned so that when doing so the muscles of the body were better prepared and avoided injury and students were more interested and excited about following the kayang movements so that students' fears could be diverted so far. become an obstacle for students.

Based on the explanation above, it is for students who have low flexibility, the application of GML is better when compared to GMI in learning floor exercise, especially the material of kayang. This is confirmed by the research results(Wake up \& Fitriyani, 2018) which states that GML can improve learning outcomes for floor exercise.

\section{CONCLUSION}

Based on the results of data analysis, the results of hypothesis testing and the results of research discussion that have been obtained, some conclusions, research implications and suggestions can be explained as follows:

1. GMI is better applied to floor gymnastics learning, especially kayang material than GML.

2. there is an interaction between teaching style and flexibility on the learning outcomes of kayang.

3. For students who have high flexibility, the application of GMI is better when compared to GML in learning floor exercises, especially the material of kayang.

4. For students who have low flexibility, the application of GML is better when compared to GMI in learning floor gymnastics, especially the material of kayang.

\section{SUGGESTION}

For learning floor gymnastics, especially kayang material, it is better to use GMI compared to exercises

\section{Recognition}

The author would like to thank Muhammad Fachrurrozi Bafadal for helping and guiding this article to completion.

\section{REFERENCES}

Aji, B. P. (2017). Penerapan GMI untuk Meningkatan Hasil Belajar Guling Lenting pada Siswa Kelas IX G SMP Negeri 8 Surakarta Tahun Pelajaran $2017 / 2018$.

Bangun, S. Y., \& Fitriyani, S. (2018). PENINGKATAN HASIL BELAJAR GULING BELAKANG SENAM LANTAI MELALUI GML PADA PELAJAR SMA. Journal Physical Education, Health and Recreation, 3(1), $1-11$.

https://doi.org/10.24114/PJKR.V3I1.115 10

Daryusman, C., Hermawan, R., \& Adam, U. (2014). PENGARUH MODEL PEMBELAJARAN BERPASANGAN DAN BERKELOMPOK TERHADAP KETERAMPILAN GERAK DASAR KAYANG. JUPE (Jurnal Penjaskesrek), 2(2).

Fis Andriyani. (2012). Dr. Olahraga Menjelaskan Senam Lantai - Fis Andriyani - Google Buku. In Balai Pustaka.

Heri Rahyubi. (2012). Teori-teori belajar dan aplikasi pembelajaran motorik. Nusa Media.

Hidasari, F. P., Natalia, L., \& Pramana, Y. (2018). Pengembangan Modul Ajar Mata Kuliah Pertumbuhan Dan Perkembangan 
Motorik Berbasis Pembelajaran Inklusi. Jorpres (Jurnal Olahraga Prestasi), 14(1), 34-45. https://doi.org/10.21831/jorpres.v14i1.19 979

Hidayat, C. (2008). MODEL INKLUSI DALAM PEMBELAJARAN PENDIDIKAN JASMANI (Studi Eksperimen di Sekolah Menengah Pertama Negeri 8 Tasikmalaya). EDUCARE, 6(1).

I Wayan Eka Putra. (2013). ANALISIS TINGKAT KECEMASAN SISWA KELAS VIII DALAM PEMBELAJARAN SENAM LANTAI GULING LENTING | . | Jurnal Pendidikan Jasmani, Olahraga dan Kesehatan Undiksha. Jurnal Pendidikan Jasmani, Olahraga Dan Kesehatan

Jamilah, G., \& Nugraheni, W. (2017). Hubungan antara Fleksibilitas Otot Perut dengan Keterampilan Gerak Dasar Kayang dalam Senam Artistik. Media Ilmu Keolahragaan Indonesia, 7(2), 5659.

Muhammad Mury Syafei. (2016). PENGARUH GAYA MENGAJAR DAN FLEXIBILITY TERHADAP HASIL BELAJAR GERAKAN TIGER SPRONG SENAM LANTAI | Syafei | JUDIKA (JURNAL PENDIDIKAN UNSIKA). Jurnal Pendidikan UNSIKA, 4(1).

Priyambada, G., KS, S., \& Handayani, O. W. K. (2016). PENGARUH GAYA MENGAJAR RESIPROKAL DAN MOTIVASI BERPRESTASI TERHADAP HASIL PEMBELAJARAN SENAM LANTAI. Journal of Physical Education and Sports, 5(1), 1-7.

Sanchez, B., Byra, M., \& Wallhead, T. L. (2012). Students' perceptions of the command, practice, and inclusion styles of teaching. Physical Education and Sport Pedagogy, 17(3), 317-330. https://doi.org/10.1080/17408989.2012.6 90864

Suryani, Y., Rukmana, A., \& Sudirjo, E. (2018). MENINGKATKAN PEMBELAJARAN SENAM KAYANG MENGGUNAKAN METODE PROGRESIF. In SpoRTIVE (Vol. 1, Issue 1).

Terry, J. J. (2016). KELENTUKAN, UMPAN BALIK, DAN METODE KOMBINASI DALAM PEMBELAJARAN SENAM
LANTAI. Jurnal Ilmu Pendidikan, 16(3). Wandi Suhendra, B. A. H. (2019). UPAYA MENINGKATKAN HASIL BELAJAR SIKAP KAYANG MENGGUNAKAN MEDIA BOLA FISIO DAN DINDING PADA SISWA KELAS V SDN JOHAR BARU 29 JAKARTA PUSAT | Jurnal Olahraga Rekreasi. Jurnal Olahraga Rekreasi, 1(1), 02. 